\title{
The Preparedness of the Rapid Reaction Team (TRC) of Aceh Disaster Management Agency in Facing Natural Disasters
}

\author{
Muzawir Amir ${ }^{1}$, Ismail AB ${ }^{2}$, Taqwaddin Husin ${ }^{3}$ \\ ${ }^{1}$ Masters in Disaster Science, Syiah Kuala University, Banda Aceh 23111, Indonesia \\ ${ }^{2}$ Faculty of Mathematics and Natural Sciences, Syiah Kuala University, Banda Aceh, \\ Indonesia \\ ${ }^{3}$ Faculty of Law, Syiah Kuala University, Banda Aceh, Indonesia \\ \{awiercasper@gmail.com\}
}

\begin{abstract}
The research entitled "The Preparedness of The Rapid Reaction Team (TRC) of Aceh Disaster Management Agency in Facing Natural Disasters" aimed to describe the level of preparedness of quick reaction team in facing natural disaster and also to figure out the effect of knowledge, attitudes, the effectiveness of exercise, and human resources on the preparedness of the quick respond team in facing natural disasters. The type of research used is a cross-sectional study design. The populations of this study were the all Aceh Disaster Management Agency (TRC) Team, which amounted to 107 people. The numbers of samples were taken by using a simple random sampling; thus, the numbers of samples taken were fewer than the populations. The data used were primary data collected in the form of questionnaires and secondary data were obtained through reports and books. The results of this study show that (1) The preparedness index of Aceh Quick Reaction Team (TRC) with a value of 95.94 belonged to very prepared category, (2) knowledge, attitudes, training effectiveness significantly influenced the preparedness of TRC personnel in responding to disasters in Aceh Province, (3) human resources consisting of age, sex and years of work did not significantly influence the preparedness of TRC personnel in dealing with disasters in the Province Aceh.
\end{abstract}

Keywords: Quick Reaction Team, Preparedness.

\section{Introduction}

Indonesia has areas prone to various disasters and if a disaster occurs, the affected people have the right to receive services and protection based on minimum service standards ranging from search, rescue, evacuation, emergency relief, fulfillment of basic needs for disaster victims including food, clothing, water clean and sanitation, health services, and temporary shelter. For this reason, a quick assessment of death victims, injuries, refugees, damage to housing/ office/ religious facilities / educational facilities, other vital facilities and infrastructure (Perka BNPB Nomor 9 of 2008) is needed [1].

The assignment of the Quick Reaction Team from various agencies/ institutions that works based on the BNPB Quick Reaction Team Procedure during disaster response due to various problems including limitation of time, urgent needs and various difficulties of coordination which may be due to the many institutions involved in handling disaster emergencies, 
competition in resource mobilization, excessive autonomy and distrust of government agencies. This requires more intensive coordination in order to facilitate the implementation of disaster emergency management (Perka BNPB Nomor 9 of 2008) [1].

BNPB/BPBD Quick Reaction Team (TRC) is a team assigned by the Head of BNP/BPBD in accordance with their authority to carry out quick disaster and disaster impact assessment activities and to provide assistance in the context of handling disaster emergencies. TRC $\mathrm{BNPB} / \mathrm{BPBD}$ consists of several cross-sectoral elements.

Aceh Disaster Management Agency (BPBA) also formed a quick reaction team (TRC) on May 7th, 2018 based on the Decree of the BPBA No. 360/758 of 2018 [2] concerning the Establishment of a Task Force for the Quick Reaction Team of Aceh Disaster Management Agency. After the existence of the Aceh Disaster Management Agency since its establishment on June 22, 2010, it has made maximal effort to carry out its main tasks and functions in carrying out disaster management services. However, there are still many things to concern in order to make improvements, one of which is the preparedness of the Aceh Disaster Management Agency's Quick Reaction Team prepared in 2018.

\section{Method}

This study used a quantitative research approach that emphasized the numerical assessment of phenomena learned through descriptive analysis methods that started by collecting data, analyzing data, and interpreting data with the type of descriptive correlation research design that is research to determine the level of relationship between two or more variables. This study used the Cross-Sectional approach, which was a type of research carried out at the same time to the independent and dependent variables.

In this quantitative research, researchers would measure the relationship of knowledge; attitude; effectiveness of training; and human resources to the preparedness of Aceh Disaster Management Agency's (BPBA) Quick Reaction Team (TRC) in dealing with natural disasters.

\section{Result and Discussion}

Quick reaction team (TRC) must be able to determine the actions to be taken when facing a disaster situation. This can be done at the time before the disaster happens which is usually called disaster preparedness. Preparedness in this study consisted of parameters of knowledge, attitudes, emergency response plans and resource mobility. These parameters are divided into variables consisting of knowledge, attitudes, training effectiveness and human resources. To determine the picture of the preparedness level in this study, it is necessary to calculate the weighting and preparedness index. Weighting is obtained from the number of questions from each parameter divided by the total number of questions. While the index is obtained by dividing the total real score divided by the maximum score then multiplied by 100 . Weighting and parameter index can be seen in Table 1 .

Table 1 shows the knowledge parameter index of 82 from 9 questions, attitudes of 97 from 9 questions, emergency response parameter index of 98 from 17 questions and resource mobility parameter index of 97 from 3 questions. 
Table 1. The Influence of Human Resources Toward Preparedness

\begin{tabular}{|c|c|c|c|}
\hline Parameter & Variable & $\begin{array}{l}\text { Weig } \\
\text { ht }\end{array}$ & IP \\
\hline Knowledge & Knowledge & 9 & 82 \\
\hline Attitude & Attitude & 9 & 97 \\
\hline $\begin{array}{l}\text { Emergency } \\
\text { Response Plan }\end{array}$ & $\begin{array}{l}\text { Exercise } \\
\text { Effectiveness }\end{array}$ & 17 & 98 \\
\hline $\begin{array}{l}\text { Resource } \\
\text { Mobility }\end{array}$ & $\begin{array}{l}\text { Human } \\
\text { Resources }\end{array}$ & 3 & 97 \\
\hline TOTAL & & 38 & \\
\hline
\end{tabular}

Source: Primary data, processed (2019)

The index of each parameter is calculated using the parameter index formula as follows:

$$
\text { index }=\frac{\text { Total rill parameter }}{\text { Maximum of parameters }} \times 100
$$

Information:

Total rill parameter: The total number of real values for all questions in parameters concerned with the total question in the parameter Maximum of parameters: The maximum number of values in the question indexed.

The parameter index of knowledge, attitudes, emergency response plans and human resource mobility is included in the very prepared category. This is because TRC has an important task such as having a task to study quickly and precisely in disaster locations within a certain time in order to identify the scope of the disaster location, the number of victims, the damage to infrastructure and facilities, the disruption to the functions of public services and government, as well as natural resource capabilities and artificial and also appropriate advice in disaster management efforts.

Based on the weight and parameter index, TRC personnel preparedness index can be calculated by the formula below:

$$
\begin{aligned}
= & (9 / 38) * \mathrm{IP} 1+(9 / 38) * \mathrm{IP} 2+(17 / 38) * \\
& \mathrm{IP} 3+(3 / 38) * \mathrm{IP} 4 \\
= & (0.23 * 82)+(0.23 * 97)+(0.45 * 98)+ \\
& (0.11 * 97) \\
= & 18.86+22.31+44.1+10.67 \\
= & 95.94
\end{aligned}
$$

Based on the calculation of the TRC members' preparedness index values, it can be concluded that the preparedness of TRC members in terms of the knowledge, attitudes, 
emergency response plans and mobility of human resources parameters belongs to very prepared category. Basically, TRC is indeed required to be very prepared because TRC is the front guard when a disaster occurs. TRC has the function of carrying out preliminary assessments immediately after a disaster and during emergency response; facilitating coordination with all sectors involved in disaster management; submitting appropriate suggestions for disaster relief efforts; and reporting the results of periodical implementation of tasks to the Head of BNPB with copies of members' direct supervisors teams from related sectors and SATKORLAK PB / Provincial BPBD/SATLAK PB/BPBD District / City, initial reports after arriving at the disaster site, periodical/developmental reports and full/final assignment reports. So basically, the TRC members must have preparedness that is very prepared in the event of a disaster.

The TRC Aceh members are parts of the BPBA which were formed with the main goal of being the first team to enter the field at the time of the disaster to carry out preliminary data on victims and to provide initial assistance to disaster victims in Aceh Province. As the earthquake in Aceh Province mostly occurs, TRC is required to maintain its preparedness in facing all possible disasters that happen in Aceh Province.

\section{Conclusion}

Based on the research results and discussion, it can be concluded as follows:

a. The preparedness index of TRC Aceh personnel is viewed from the knowledge, attitudes, emergency response plans and resource mobility parameters consisting of variables of knowledge, attitudes, training effectiveness and human resources amounted to 95.94, which means that they belong to the very prepared category.

b. The chi-square test results showed a partial variable of knowledge that has a value (assymp. sig of 0.012), attitude variable that has a value (assymp. sig of 0.041), and exercise effectiveness variable that has a value (assymp. sig of 0.034) significantly influenced the preparedness of TRC personnel in handling disasters in Aceh Province. Meanwhile, the human resource variable consisting of age that has a value (assymp. Sig of 0.747 ), gender that has a value (assymp. Sig of 0.430), and work period that has a value (assymp. Sig of 0.595 ) did not significantly influence the preparedness of TRC personnel in dealing with disasters in Aceh Province.

\section{REFERENCES}

[1] Perka BNPB Nomor 9, Prosedur tetap tim reaksi cepat badan nasional penanggulangan bencana. Jakarta, 2008.

[2] Keputusan Gubernur Aceh Nomor 360/758/2018, Tentang pembentukan tim reaksi cepat penaggulangan bencana aceh. 2018. 